\title{
Subject
}

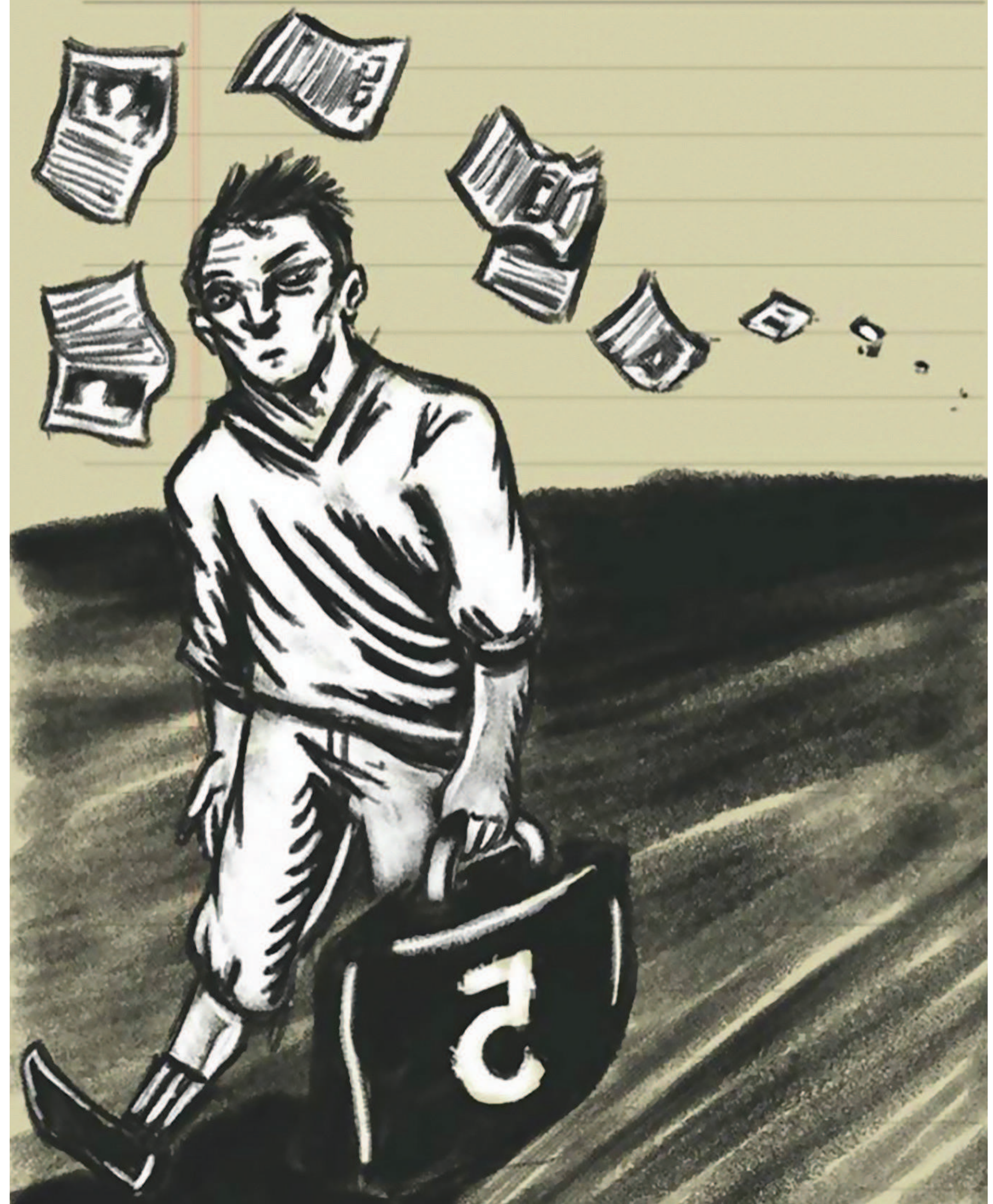



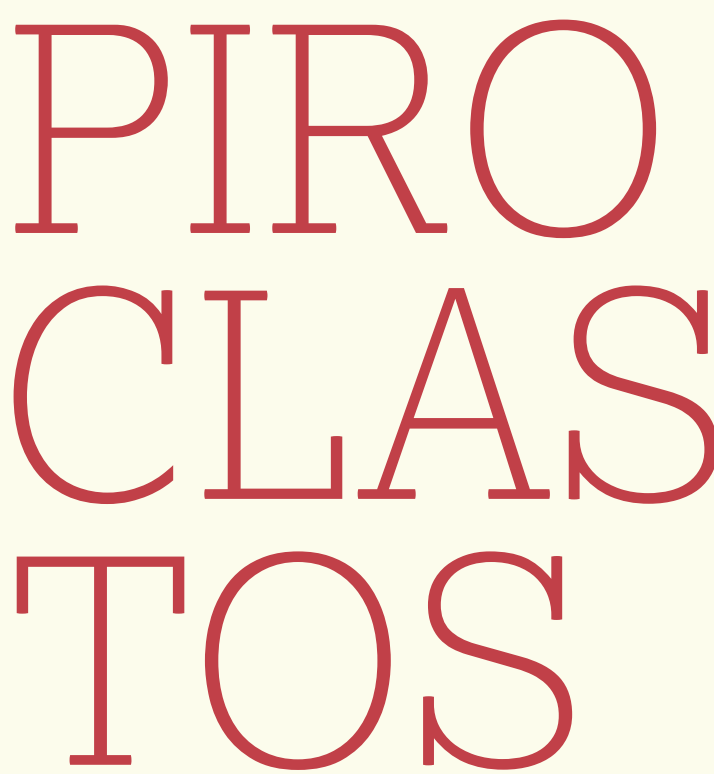

Do grego piro + klastós, -é, -ón.

Fragmentos de fogo expelidos durante a erupção e que solidificam. 


\section{AS MÃES DE MAIO}

- PÁDUA FERNANDES

nós vimos através

dos buracos da mão

que as balas deixaram

quando ele tentou se proteger;

nós vimos através

das rachaduras no berço

após atirarem em galhofa

na barriga de nove meses:

"antes de nascer um ladrão,

roubamos dele o nascimento";

(decretada a proibição dos velórios

por excesso de mortos)

nós vimos através

da porta da rua aberta

com a chegada do despejo coletivo

após executarem em plena rua

os que podiam pagar o aluguel;

através da perícia

jamais realizada

nas armas do Estado

encapuzadas de dinheiro e sangue;

(o Estado continua seu trabalho:

saindo do velório permitido,

os jovens caem baleados)

através do parecer jamais escrito

pelo procurador-geral; através 
da decência do governador

e outras imaterialidades,

sua inocência de declarar

"não foi morto quem já não vivia";

vimos através da agenda presidencial

inexistente

para tratar dos que não existem ao poder;

(os que não caem são presos,

presos porque vivem)

através dos gritos

calados no túmulo

pelas folhas da imprensa

pelo estado da imprensa

para a qual eles nunca viveram;

vimos através da declaração de guerra

jamais feita

porque as bombas são tão mudas quanto os corpos;

(presos porque, mesmo autorizado,

um velório denuncia

a natureza do Estado)

das trompas e ovários extirpados pela dor;

dos netos não nascidos

ainda brincando no quintal;

através de todo esse longo túnel

aberto na carne deste país,

nós vimos

o próprio país, um acidente

arrancado ao mundo,

e reconhecemos sua bandeira

nos rasgos dos panos 
que cobrem os corpos

deixados à rua

todos os dias, todos os meses,

como os de nossos filhos

PÁDUA FERNANDES (Rio de Janeiro, 1971) é autor dos livros de poesia O palco e o mundo (Lisboa: \& etc, 2002), Cinco lugares da fúria (São Paulo: Hedra, 2008), Cálcio (Lisboa: Averno, 2012; São Paulo: Hedra, 2015), traduzido para o espanhol por Anibal Cristobo e publicado na Argentina (Calcio, City Bell: De la Talita Dorada, 2013) e Código negro (Desterro: Cultura e Barbárie, 2013). Publicou o livro de contos Cidadania da bomba (E-Galáxia e Patuá, 2015). Mantém o blogue $\mathrm{O}$ palco e o mundo (opalcoeomundo.blogspot.com). 